NBER WORKING PAPER SERIES

\title{
DID RAILROADS INDUCE OR FOLLOW ECONOMIC GROWTH? URBANIZATION AND POPULATION GROWTH IN THE AMERICAN MIDWEST, 1850-60
}

\author{
Jeremy Atack \\ Fred Bateman \\ Michael Haines \\ Robert A. Margo \\ Working Paper 14640 \\ http://www.nber.org/papers/w14640 \\ NATIONAL BUREAU OF ECONOMIC RESEARCH \\ 1050 Massachusetts Avenue \\ Cambridge, MA 02138 \\ January 2009
}

The views expressed herein are those of the author(s) and do not necessarily reflect the views of the National Bureau of Economic Research.

NBER working papers are circulated for discussion and comment purposes. They have not been peerreviewed or been subject to the review by the NBER Board of Directors that accompanies official NBER publications.

(C) 2009 by Jeremy Atack, Fred Bateman, Michael Haines, and Robert A. Margo. All rights reserved. Short sections of text, not to exceed two paragraphs, may be quoted without explicit permission provided that full credit, including $(\mathcal{C}$ notice, is given to the source. 
Did Railroads Induce or Follow Economic Growth? Urbanization and Population Growth in the American Midwest, 1850-60

Jeremy Atack, Fred Bateman, Michael Haines, and Robert A. Margo

NBER Working Paper No. 14640

January 2009

JEL No. N12,N71,O14,O18

\begin{abstract}
$\underline{\text { ABSTRACT }}$
For generations of scholars and observers, the "transportation revolution," especially the railroad, has loomed large as a dominant factor in the settlement and development of the United States in the nineteenth century. There has, however, been considerable debate as to whether transportation improvements led economic development or simply followed. Using a newly developed GIS transportation database we examine this issue in the context of the American Midwest, focusing on two indicators of broader economic change, population density and the fraction of population living in urban areas. Our difference in differences estimates (supported by IV robustness checks) strongly suggest that the coming of the railroad had little or no impact upon population densities just as Albert Fishlow concluded some 40 years ago. BUT, our results also imply that the railroad was the "cause" of midwestern urbanization, accounting for more than half of the increase in the fraction of population living in urban areas during the 1850 s.
\end{abstract}

Jeremy Atack

Department of Economics

Vanderbilt University

VU Station B \#351819

2301 Vanderbilt Place

Nashville, TN 37235-1819

and NBER

jeremy.atack@vanderbilt.edu

Fred Bateman

Department of Economics

Brooks Hall

University of Georgia

Athens, GA 30602-6254

fbateman@terry.uga.edu
Michael Haines

Department of Economics, 217 Persson Hall

Colgate University

13 Oak Drive

Hamilton, NY 13346

and NBER

MHAINES@MAIL.COLGATE.EDU

Robert A. Margo

Department of Economics

Boston University

270 Bay State Road

Boston, MA 02215

and NBER

margora@bu.edu 


\section{Did Railroads Induce or Follow Economic Growth? Urbanization and Population Growth in the American Midwest, 1850-60}

Over half a century ago, George Rogers Taylor (1951) celebrated what he believed to be the central role played by "[t]he Transportation Revolution" in America's social and economic changes during the nineteenth century. According to Taylor, nowhere were these changes greater than in the Midwest. There, in less than two generations, a sparsely populated frontier region was transformed into the world's bread basket, an industrial heartland and home to the $7^{\text {th }}, 8^{\text {th }}$ and $9^{\text {th }}$ largest cities in the United States. When Ohio achieved statehood in 1803 , the only ways into the region were by sail, paddle, or on foot. Eight years later, the New Orleans had successfully demonstrated the feasibility of steam navigation on the Ohio and Mississippi rivers. By 1818, the National Road had reached eastern shore of the Ohio River at Wheeling and in 1832 the first canal in the region, the Ohio and Pennsylvania, opened to traffic. In the years that followed, not only did these transportation networks spread throughout the region but they were joined by a new medium, the steam railroad. Collectively, they provided evereasier means of entry for new migrants and ever-cheaper means for the export of the region's produce.

The potential economic impact of improved transportation was recognized from the very beginning. For example, 200 years ago, Treasury Secretary, Albert Gallatin, in his famous report on "Roads and Canals" to Congress noted "good roads and canals will shorten distances, facilitate commercial and personal intercourse, and unite, by still more intimate community of interests, the most remote quarters of the United States” (U. S. Congress., Senate 1808). The net result, he argued, would be an increase in national 
wealth. Consequently, he advocated the "early and efficient aid of the Federal [emphasis in the original] government" to mediate market failures and the externalities associated with the supply of these transportation services (Paskoff, Paul F. 2007). Many states also took this advice to heart with the result that most of the roads and canals were built with state sponsorship (Goodrich, Carter 1961).

Although it was the latecomer to the transportation revolution, the railroad quickly rose to dominance. By 1840 , there were about as many miles of railroad in operation as canals (Taylor, George Rogers 1951 p. 79). A decade later, railroad mileage exceeded that of canals by more than two to one and was closing in on the total miles of navigable waterway in the Mississippi and Ohio river system (Taylor, George Rogers 1951 p. 79); (Hunter, Louis C. 1949) and, by 1860, the United States had more miles of railroad than the rest of the world combined (Mitchell, B. R. 2003, Series F1, pp. 673-4). Moreover, the American Midwest which, at the start of 1836, had no railroads was, by the mid-1850s, the focus of much of this rail construction. Indeed, between 1853 and 1856, more than half the track miles built were built in the Midwest and, in 1856, this share reached a remarkable $75 \%$, of which almost $40 \%$ was built in just one state, Illinois(Carter, Susan B., Scott Sigmund Gartner et al. 2006 Series Df882); (Fishlow, Albert 1965, p. 172).

According to Leland Jenks, the expansion of this railroad network into the Midwest "to link the seaboard with the interior, the Ohio Valley with the Great Lakes, and, breaking away from the contours of water transport, to unite distant points by more direct routes ... gave the 'railroad idea' prolonged force in American economic life. The conviction that the railroad would run anywhere at a profit put fresh spurs to American 
ingenuity and opened closed paddocks of potential enterprise" (Jenks, Leland H. 1944 pp. 2-3).

Jenks was far from the first person to make the claim that the railroads preceded economic development. A New Orleans Picayune editorial from 1860 claiming the "nine-tenths of our roads when first traversed by steam pass through long ranges of woodlands in which the ax has never resounded, cross prairies whose flowery sod has never been turned by the plow, and penetrate valleys as wild as when the first pioneers followed upon the trail of the savage..." (Fishlow, Albert 1965) and a British investment adviser of the late nineteenth century, Salomon Frederik Van Oss (1893), opined to the investing public "the American railroad came in advance of the settlers."

Certainly, between 1840 and 1860, a period which includes the first construction boom in American railroads, population flooded into the American Middle West. Wisconsin's population increased more than 20-fold in these two decades; Michigan's grew 15-fold and even Illinois saw its population grow almost four-fold. Moreover, vast areas of territory were transformed from what the federal government identified as "frontier"- areas where population density was below six persons per square mile (essentially less than one typical family per square mile) — to settled, and even urban, communities. Indeed, densities in the counties surrounding the cities of Cincinnati, St. Louis and Milwaukee averaged over 250 persons per square mile by 1860 .

In the East, railroads and canals essentially developed alongside one another. America's first railroad, the Baltimore and Ohio, for example, was chartered just eight years after the very first section of the Erie Canal (between Rome and Utica) had ushered in the canal age in America. Moreover, the limited power of early locomotives and the 
economics of railroad and canal construction and operation which placed a premium on a level grade and led both media to follow the same routes as natural waterways.

Railroads in the East, as the comparative latecomer if only by a few years, tended to supplement existing transportation media. Eventually though, railroads were forced to strike out on their own. At no time or place was this more obvious than in the push to build the transcontinental railroads linking the East and West coasts together in the 1860s. Even before that, however, the railroads had begun to spread out as the mountain valleys of the Appalachians gave way to the broader plains in the Midwest and lower population densities of a newly settled agricultural region. It was there, in the Midwest, that Fishlow (1965) sought to determine whether railroads were "built ahead of demand". As he noted

"the magnitude of these changes in the transportation sector was fully matched by changes in other parts of the western economy [and while] ... a theoretical structure invoking lower transport costs can explain [the changes in the economy] ... such a logical relationship does not establish unequivocal causality. If population migrations had already extended the agricultural frontier, if urban agglomerations had already become prominent, transportation improvements may have justified and reinforced such development rather than initiated them." (Fishlow, Albert 1965 1634)

\section{Moreover,}

“A key issue, however, is whether such railroad influence was primarily exogenous or endogenous, whether railroads first set in motion the forces 
culminating in the economic development of the decade, or whether arising in response to profitable situations, they played a more passive role.” (Fishlow, Albert 1965 p. 203)

It is this issue of causality that we have returned to here. In his analysis, Fishlow looked at a number of different indicators: whether or no investors demanded a risk premium on construction bonds, the pattern of ex post profitability of the Midwestern rail roads and the pattern of rail construction relative to population density. However, at no point did he attempt to measure the impact of the railroad per se on any economic outcomes. Here, we focus on population density and, in particular, a key related indicator of economic development - the extent of urbanization - quantifying the contribution of the railroad using a number of techniques that have been developed since Fishlow wrote his book. Specifically, GIS lets us map the nineteenth century railroad network with a degree of precision and coherence unavailable to earlier researchers while some more recent methods have the potential to deal with the econometric problems to which Fishlow drew attention.

\section{Railroad Expansion in the Midwest}

Although Ohio was the first of the Midwestern states to be admitted to the Union and was by far the most populous state west of the Appalachians until the 1880s, it was not the first state in the region to adopt the new rail technology. Indeed, having invested heavily in the earlier canal technology, Ohio initially tried hard to discourage the interloper from devaluing the state's existing infrastructure investment. Instead, the honor of having the first rail service in the region went to Michigan which was then not yet a state. The territorial legislature had chartered the Pontiac and Detroit Railroad in 
1830 but service on that line did not begin until 1838 , with steam service starting the following year. By then, a second line, the Erie and Kalamazoo Railroad, chartered in 1833, had finished its railroad from Port Lawrence, Michigan (now named Toledo, Ohio) at the western end of Lake Erie to a point on the Kalamazoo River which would then (theoretically) provide a link across the state to Lake Michigan. It opened to steam service in 1837 between Toledo and Adrian (Dunbar, 1969; Merints, 1992). ${ }^{2}$ Railroad construction in Ohio began in 1835 and by 1837 the Mad River and Lake Erie railroad was operating on a 4' 10 " gauge. This non-standard gauge was to become the standard gauge in Ohio but, happily, the difference between this "Ohio gauge" and standard gauge (4' $8 \frac{1}{2}$ ") was sufficiently small that each could accommodate the locomotives and rolling stock of the other within the margin of error provided by the wheel tread.

Despite these pioneering efforts, rail construction did not begin in earnest in the Midwest until the late 1840s. Once underway, though, it proceeded rapidly (mostly on a gauge compatible with the standard 4' $8 \frac{1}{2}$ " track, with the notable exception of the Ohio and Mississippi railroad linking Cincinnati with [East] St. Louis which was built on a 6 foot gauge) and the region dominated new construction in several years. Figure 1 displays the rail network in the seven Midwestern states (without distinction with regard to gauge) as of 1850 and 1860 and we focus upon those counties which gained access to a railroad during the 1850 compared with those which still did not have rail access by 1860.

\footnotetext{
${ }^{2}$ One important point to this discussion is the distinction between authorization, construction, completion and the beginning of regularly scheduled steam service. Our data on the Midwest come from contemporary travel guides and thus clearly refer to regularly scheduled rail service.
} 


\section{The Data}

The data used in this study come from two quite different sources. The first is a newly constructed geographic information system (GIS) database on transportation infrastructure for the nineteenth century United States based upon the work of Paxson (1914) supplemented by a variety of other, largely contemporary, sources from which we have created "shapefiles" that geo-locate these features. The second data source is the well-known "Historical, Demographic, Economic, and Social Data: The United States, 1790-1970" (197?), as revised and supplemented by Haines.

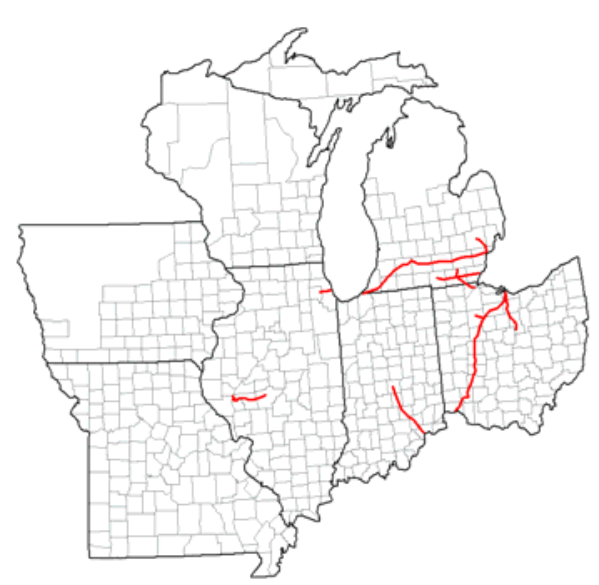

1850

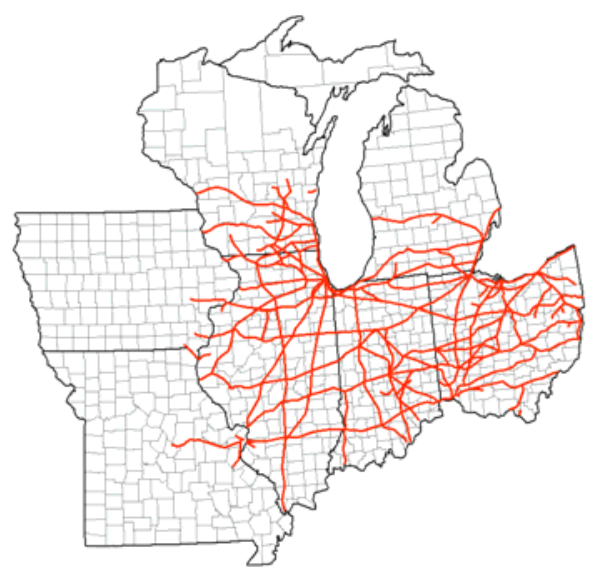

1860

Figure 1: Progress of Railroad Construction in the Midwest, 1850-1860 


\section{Our GIS database for the Midwest is part of a larger project on transportation that}

will eventually yield similar data covering the entire country during the nineteenth and early twentieth centuries. The GIS methodology has a number of advantages over the approach taken by previous historians that typically involved matching historical transportation maps to county boundary maps by hand (and eye). ${ }^{3}$ In recent years, however, libraries and archives across the United States have begun to digitize their holdings, including historical maps. Compared with the traditional method (which, in

\footnotetext{
${ }^{3}$ See, for example, Craig, Palmquist, and Weiss (Craig, Lee A.; Palmquist, Raymond B., and Weiss, Thomas 1998)), who visually compared historical maps to county boundaries (which generally did not appear on the historical maps). Their procedure is described as follows:

"The way in which the counties were coded was simple: I reserved space in our library's map room one summer ('96, I think). I then collected histories containing maps of transportation improvements in general and the railroad industry in particular. (These include the histories cited in the JREFE article in the issue you edited.) I also had the librarians dig out old maps that had county lines on them. (I don't think these maps are cited in the paper. In fact, there were many of them and the librarians just laid them out forme.) I then spent much of the summer going one county at a time from the ICPSR list for 1850 and 1860 , visually IDing if a particular railroad (or canal or river) ran through that county in that year.

As for the coding itself, there were four specific problems that I ran into, each of which might reasonably lead to some counties being coded differently using a different approach.

One was that the counties themselves changed over time. I did not always have a local map with the counties in the exact year that I needed. In these cases my rule was to use the ICPSR county names for the counties in question and the map that was the closest in date to the year in question - though "closest in date" here often meant much later. (This also created some problems when we did the maps in the paper i.e. Figures 1 and 2. The technician who knew the software mapped the counties in the data files into GIS; thus the counties in the figures most likely reflect 1990 boundaries.)

Two was that the railroad maps did not always agree with one another - that is, some maps had some lines that did not appear on or in other sources, and the years in which various lines opened were not always consistent. In these cases my rule was to accept the rail lines I saw. In other words, if source A had a line that source B did not, then I used source A.

Three was that the rail maps did not have county boundaries on them; so I had to either (a) eyeball where the lines ran on the maps with counties or (b) in some cases I had later maps that had later rail lines that looked to follow the same route as the 1850 or 1860 lines. In those cases where I had a later map, and they looked to be the same route, I used (b); otherwise I used (a). In either case, it was eyeballing, because even in case (b) I was eyeballing to make sure the line in question followed the some route on both maps.

Finally, there were clearly some counties, usually small counties, especially in New England, that had "rail access" but no railroads running directly through them. Our rule was: counties that had no rail line but were within 10 miles of a rail line in two or more adjacent counties - and that were not separated by a major natural obstacle, such as a navigable river or mountain range were coded as having rail access." Personal email correspondence with Lee Craig, 6/26/2007.

It should be noted that the traditional approach has one advantage over GIS - namely, that it is more forgiving of imperfections in the original maps (for example, inaccurate surveys) that can sometimes make accurate use of GIS close to impossible.
} 
this case, would involve printing out the digitized maps and hand-eye tracing) GIS is more efficient and (potentially) more accurate at transforming such materials into a machine-readable database. Also as we note below, GIS can also be used to create digital renderings from paper sources, which can be incorporated directly into the database after software processing.

For five of the Midwestern states (Indiana, Illinois, Michigan, Ohio and Wisconsin), we have been able to generate a complete and consistent GIS dataset. The raw materials for this were assembled over ninety years ago by an army of students from the University of Wisconsin who used extant contemporary travel guides, giving route maps and timetables for the convenience of the travelling public, to draw a series of small scale maps showing the spreading rail network in these states between 1848 and 1860 (Paxson, Frederic L. 1914). These travel guides first appeared in the 1840s and include Disturnell's Guide (Disturnell, John 1846), Doggett's Gazetteer (Doggett, John 1847), Appletons' Guide (Appleton D. and Company. 1848), Dinsmore's Guide (Cobb, Charles 1850), Lloyd's Guide (Lloyd, E. 1857), Travelers' Guide (National Railway Publication Company. 1868) and The Rand-McNally Guide (Rand-McNally 1871). Some of these were published monthly; others, semi-annually or annually. Each typically went through many editions. ${ }^{4}$

\footnotetext{
${ }^{4}$ Unfortunately, as ephemera, relatively few have survived to the present and we have yet to assemble enough of them to construct as complete a time series as that to which Paxson's students had access. All of the guides that we have physically handled are fragile, especially the multi-page fold-out maps, and not sturdy enough for scanning or copying, although a few guides have been digitized and are available on-line. See, for example, the June 1870 copy of the Travelers' Official Railway Guide at http://cprr.org/Museum/Books/I ACCEPT the User_Agreement/Travellers Guide 6-1870.pdf from the Central Pacific Railroad Museum. There are also at least two different editions of Appleton's Guide on Google Books such as http://books.google.com/books?vid=UOM39015016751375 as well as a number of other guides. See http://www.lib.utexas.edu/maps/map_sites/hist_guide_sites.html
} 
The belief that these travel guides represented the best possible sources of information about rail service is market-driven and supported by contemporary claims. Competition and frequent publication should have ensured that only the more useful of these guides survived. Dinsmore's guide, for example, was singled out for praise by one of the leading commercial/business publishers of the time: Hunt's Merchants' Magazine.

We are indebted to the publishers for a copy of the last number of their NEW GUIDE; and must say that for conciseness, mingled with complete information, neatness of execution, and convenience of reference, it fully equals our expectations of what a Railroad Guide should be. Besides the usual tables of distances, times, and fares, the traveler is provided with a handsome and complete railroad map of the whole country, and small maps of the great centers and trunk lines, with tables of reference to the details of the lines represented on them, and very perfect tables of steamboat lines on the principal rivers and waters; and appended to the whole is an excellent Railroad Gazetteer. Dinsmore, as he has always done, keeps up with the times ; and it is a great inducement for him to do so, that he may furnish correct information for those whose lack of originality leads them to copy from him. We can unhesitatingly recommend Dinsmore's American Railroad and Steam Navigation Guide. (Hunt, Freeman, Thomas Prentice Kettell et al. 1848 36, January-June 1857. p253)

Paxson's maps compiled from these sources have been digitally rendered in GIS and fitted to other mappings of rail routes (most notably those prepared by Taylor and Neu 
(1956)) for the same period and assembled from similar sources. ${ }^{5}$ The GIS-generated estimates of the railroad mileage are within three percent of the state totals reported by Paxson. ${ }^{6}$

For Iowa, Fishlow used data from Henry Varnum Poor (Poor, Henry V. 1868).

Other scholars, however, have raised serious questions about these data. Elmus Wicker, for example, has written

“I have attempted to evaluate Poor's data for $1830-60$ by comparing his estimates with those prepared by Armin Shuman for the 1880 census and also with my own estimates for eight states ... One plausible explanation for the discrepancy is that the differences are due simply to errors of reporting. Furthermore, there is some ambiguity as to what exactly is being measured ... I think that the total mileage evidence clearly shows the unreliability of Poor's annual data ... shortcomings in Poor's data arise also from the variety of purposes for which they have been employed ..." (Conference on Research in Income and Wealth., National Bureau of Economic Research. et al. 1960, 505, 507, 508).

As an alternative to Poor's retrospective data, we used state maps from the David Rumsey Map Collection (http://www.davidrumsey.com/) to chart the spread of railroads in Iowa and Missouri. However, it was not possible to find a map for each state in each year and these data are less satisfactory than the travel guide data used by Paxson for a

\footnotetext{
${ }^{5}$ Indeed, such sources were used by Taylor and Neu (Taylor, George Rogers and Irene D. Neu 1956) in drawing up their maps of the US rail network as of April 1861 and also seem to have been relied upon by Paxson.

${ }^{6}$ We compute the county by county mileage using the AnalysisTools/Overlay/Intersect tool with the decennial county boundary layers for the five Midwestern states and the entire railroad network in the region as of 1861. This generates a new layer composed of segments of each railroad's track within each county in each year. Linkage with the Taylor-Neu data in particular also generates information regarding each railroad's track gauge which was not standardized at 4' $8 \frac{1}{2}$ " until the 1880 s.
} 
variety of reasons. Dates on the maps tend to be ambiguous. Most list their copyright date rather than the date represented by the data on the map. In drafting their maps, the mapmakers were attempting to capture a flow—railroad construction—as a snapshot. Consequently, even the most accurately drawn map which spent a month or two in production might miss more new railroad mileage that was built during that period than had existed in the entire country in the 1830 s or early 1840 s. $^{7}$ Some mapmakers tried to anticipate this fluidity by building in their expectations for near term future expansion into their maps, only to see those plans go unrealized as funding fell through or construction was temporarily halted. Moreover, few of the mapmakers had personal knowledge of all of the rail systems they were drawing and so relied upon secondhand information. Last, and certainly not least, rail lines were not accurately and consistently drawn on maps with the result that railroads sometimes appear to shift location from year to year. A few of these may have been realigned and re-graded. ${ }^{8}$ However, in most cases, once a railroad was built in a specific location; it stayed there because the bulk of the railroad's investment was not just fixed but also sunk. ${ }^{9}$

The rail data have been supplemented with information on navigable waterways from Goodrich (1961) and Hunter (1949) along with various nineteenth century sources such as Poor (1860) and contemporary maps (for example, Disturnell's 1850 map of the

\footnotetext{
${ }^{7}$ (Carter, Susan B., Scott Sigmund Gartner et al. 2006 Tables Df882 and Df884)

${ }^{8}$ For example, following the merger of Boston and Lowell Railroad with the Boston and Maine in 1845, track between Wilmington and Boston was initially abandoned (only to be later reused by the B\&L for their Wildcat Branch). In 1848, the Boston and Maine abandoned another original section of track as a new alignment was built from Wilmington north to North Andover so as to better serve Lawrence. In 1873, a new alignment to Portland was opened splitting from the old route at South Berwick and the old route was subsequently abandoned. http://www.answers.com/topic/boston-and-maine-railroad

${ }^{9}$ For example, according to the 1880 Census, over 80 percent of railroad investment went into construction costs, of which only one or two percent represented the cost of the land itself; the rest went in surveying, grading, removing or bridging obstacles and laying the track. While ties, ballast and the rails might be reused and the land itself could be resold, the grading, cuttings, embankments, bridges, and drainage ditches had few alternative uses - especially in the nineteenth century although today many have found recreational use in the "rails to trails" movement.
} 
United States "showing all the canals, railroads, telegraph lines and principal stage routes" (Burr, Henry A. 1850)). ${ }^{10}$ The nature of these sources is such that we measure water access as of a benchmark date -1850 - rather than change over time. Thereafter, however, there were few additions to waterways anywhere in the country.

Although the GIS software can, in principle, produce a wide range of different measures of transportation access - such as the fraction of land that lay within $x$ miles of a railroad - here, we have used a simple binary variable, ACCESS, indicating whether or not a particular transportation medium crossed or formed a border for each county in existence at the census benchmark dates. ${ }^{11}$ Thus, our end product is a county-level panel data set showing whether a county had rail access in 1850 or 1860 , and whether the county had water access in 1850 .

By construction, all of the variation in access occurs in the rail variable.

Consequently, we focus on the effects of gaining rail access. To this end we have linked our GIS data to the county-level Haines-ICPSR census data using FIPS codes, restricting our analysis to those counties that were (1) present beginning in 1840, (2) which had the same county boundaries as determined by square mileage, and (3) which did not have rail access as of 1850 . These restrictions limit the panel to 278 Midwestern counties,

\footnotetext{
${ }^{10}$ In determining whether a river was navigable, we adopted a pragmatic viewpoint and defined a navigable waterway as one which accommodated steamboats on a regular basis - that is we required evidence of more than one successful voyage and excluded those waterways used only by batteaux. Thus, for example, we excluded the White River in Indiana and the Miami and the Scioto in Ohio. Our tabulation of navigable rivers, on the other hand, includes the Wisconsin River which, for some reason was not included in the 1890 Census of Transportation tabulations and thus excluded by Fogel (1964) from his analysis. In nineteenth century, steamboats navigated the Wisconsin River from its junction with the Mississippi River at as least as far as Portage in Columbia County (and close to the head of navigation of the Fox River) and sometimes ventured as high as Nekoosa in Wood County. See http://www.hmdb.org/marker.asp?marker=1193.

${ }^{11}$ We rely on a simple binary measure of access because at present the GIS overlays (that is, the digitized railroad map relative to digitized county boundaries at our disposal) are insufficiently accurate, in our view, to construct fully reliable measures of total mileage.
} 
distributed as shown in Table 1. Our use of some data from 1840 eliminates many counties in northern Michigan and Wisconsin and those in Iowa located further back from the Mississippi River. ${ }^{12}$ These restrictions are driven in large part by our choice of “differences-in-differences” as our primary estimation strategy.
Table 1: Distribution of Counties by State: Balanced Panel of Counties with Fixed County Boundaries

\begin{tabular}{|l|l|l|}
\hline State & Number of counties & Percent of Total \\
\hline Illinois & 71 & $25.5 \%$ \\
\hline Indiana & 66 & 23.7 \\
\hline Michigan & 12 & 4.3 \\
\hline Ohio & 57 & 20.5 \\
\hline Wisconsin & 14 & 5.0 \\
\hline Iowa & 17 & 6.1 \\
\hline Missouri & 41 & 14.8 \\
\hline Source: &
\end{tabular}

Source: linked sample of counties, 1850 and 1860 census, with transportation database. To be included counties must be (1) present in 1840, 1850 and 1860 (2) have fixed county boundaries (3) did not have rail access in 1850 but gained rail access by 1860 (treatment group) or did not have rail access in both 1850 and 1860 (control group). There are 278 counties in the sample..

In this approach, the data are divided into two groups: a "treatment group" and a “control group." In our case, the treatment is gaining rail access in the 1850s.

Consequently, our treatment group consists of those counties that did not have rail access in 1850 but which did by 1860 . The most natural control group with which to contrast the treatment group is those counties that did not have rail access in either 1850 or 1860 . Use of 1840 data then allows us also to control for pre-existing trends in the counties.

\footnotetext{
${ }^{12}$ Results are qualitatively the same if we do not impose the restriction that the county not have rail access by 1850 and if we do not impose the requirement that county boundaries be the same in 1840 as in 1850 and 1860. Quantitatively, the effect of imposing these restrictions is to reduce estimated of rail access on urbanization and population density - that is we have biased the results against Fishlow's and our hypothesis.
} 


\section{Measuring the Effect of the Railroad on Population Density and Urbanization}

To estimate the economic impact of the railroad we need county-level indicators of economic development that are consistently defined over time. Although there are a number of possibilities in the census data (some of which were suggested by Fishlow), we have chosen to focus on two related measures_-population density and the fraction of a county's population living in urban areas. ${ }^{13}$ These are among the most reliable and consistently defined numbers reported by the censuses and there are, as Fishlow himself pointed out and as we discuss later, good economic reasons to expect that transportation improvements like the railroad would have a positive effect upon population growth and urbanization.

By construction, none of the counties in our sample had rail access in 1850. By 1860 , however, 195 of the 278 counties making up almost 72 percent of the land area in the panel had direct access to at least one railroad (Table 2). Weighted by population, the increase was even more impressive with 78 percent getting access to rail during the 1850s. Population per square mile grew an average of almost 76 percent (that is $\exp (0.565)-1 \times 100$ percent as we report the log change to emphasize population growth rather than absolute numbers) and the fraction of population living in urban areas grew from 6.7 percent to 11.7 percent. Weighted by county population, the increase in urbanization was slightly smaller, 4.8 percentage points.

\footnotetext{
${ }^{13}$ Our definition of urban follows the census convention - persons living in incorporated villages, towns, or cities with a population of 2,500 or more.
} 
Table 2: Sample Statistics: Sample Means of Percent Urban, Log Population Density, and Rail Access in 1850 and 1860: Balanced Panel of 278 Midwestern Counties

\begin{tabular}{|l|l|l|l|}
\hline & 1850 & 1860 & $1860-1850$ \\
\hline Rail =1 & 0 & $0.717\{0.785\}$ & $0.717\{0.785\}$ \\
\hline Percent Urban & 0.067 & 0.117 & 0.048 \\
\hline $\begin{array}{l}\text { Log } \\
\text { (Population/Square } \\
\text { Miles) }\end{array}$ & 2.882 & 3.447 & 0.565 \\
\hline
\end{tabular}

Source: see text and Table 1. The sample consists of counties that gained rail access between 1850 and 1860 (treatment group) and counties that did not have rail access before the Civil War (control group); see the notes to Table 1. Rail = 1 if railroad passes through county boundary, 0 otherwise. By construction, no counties have rail access in 1850. Percent urban $=$ Population residing in villages, town, cities of 2,500 or more/Total population. Log population density $=\log$ (Total population/land area of county in square miles). Figures outside of \{\} in columns 2 and 3 are weighted averages of county values. For percent urban, the weight is the county's average population in 1840,1850 , and 1860. For rail access and log of population density, the weight is county's square miles in 1850 . Column $4=$ Column $3-$ Column $2 .\{\}$ : counties are weighted by average population in 1840,1850 , and 1860 .

Table 3 reports our base differences in differences. We compute the decadal changes in the outcome (percent urban or log population density) separately for the treatment group (counties that gain rail access) and the control group (counties without rail access before the Civil War). As can be seen from the figures in column 6, row 3 of either panel, the increases in urbanization or population density between were larger for the treatment counties than the control counties. In the case of urbanization, the "excess" growth in urbanization attributed to the coming of the railroad in the $1850 \mathrm{~s}$ is 3.7 percentage points, with a standard error of 1.2 points. Not only is this effect statistically significant, it is economically quite large considering that the sample mean value of percent urban in 1850 was only 6.7 percent. By contrast,, the effect of railroad expansion looks to be very modest, $0.032 \log$ points, or 3.2 percent, and not statistically significant. 
Table 3: Differences in Urbanization and Population Density between the Control And Treatment Counties, 1840-1860 in the Balanced Panel.

Panel A: Base Differences-in-Differences: Percent Urban

\begin{tabular}{|l|l|l|l|l|l|l|}
\hline & $\mathrm{N}$ & 1840 & 1850 & 1860 & $\begin{array}{l}1860- \\
1850 \\
(\mathrm{DD})\end{array}$ & $\begin{array}{l}1850- \\
1840\end{array}$ \\
\hline Treatment & 195 & 0.029 & 0.084 & 0.143 & 0.059 & 0.055 \\
\hline Control & 83 & 0 & 0.003 & 0.025 & 0.022 & 0.003 \\
\hline $\begin{array}{l}\text { Treatment } \\
\text { - Control }\end{array}$ & & 0.029 & 0.081 & 0.118 & $\begin{array}{l}0.037^{*} \\
(0.012)\end{array}$ & 0.058 \\
\hline
\end{tabular}

Source: see text and Tables 1 and 2. Treatment: county did not have rail access in 1850 but gained rail access by 1860 . Control: no rail access before the Civil War.

Figures shown in columns 3-5 are weighted averages of county values; weight is the county's average population in 1840, 1850, and 1860. Column $6=$ Column $5-$ Column 4. Column $7=($ Column $4-$ Column 3). DD: differences-in-differences. (): standard error. *: significant at the 5 percent level.

Panel B: Base Differences-in-Differences: Log of Population Density

\begin{tabular}{|l|l|l|l|l|l|l|}
\hline & $\mathrm{N}$ & 1840 & 1850 & 1860 & $\begin{array}{l}1860- \\
1850 \\
(\mathrm{DD})\end{array}$ & $\begin{array}{l}1850- \\
1840\end{array}$ \\
\hline Treatment & 195 & 2.224 & 2.953 & 3.527 & 0.574 & 0.733 \\
\hline Control & 83 & 2.148 & 2.703 & 3.245 & 0.542 & 0.555 \\
\hline $\begin{array}{l}\text { Treatment } \\
\text { - Control }\end{array}$ & & 0.076 & 0.250 & 0.282 & $\begin{array}{l}0.032 \\
(0.052)\end{array}$ & 0.178 \\
\hline
\end{tabular}

Source: see text and Tables 1 and 2. Figures in columns 3-5 are weighted averages of county values; weight is county land area in square miles (1850). (): standard error.

Ideally in a differences-in-differences analysis we would like to "match" the treatment and control counties so that the groups are otherwise similar except for the treatment. However, this was clearly not the case with respect to either the levels of urbanization and population density in 1850 , or trends in these over the 1840 s. Indeed, the differences are quite stark. As early as 1840 , almost three percent of population in the treatment group lived in urban areas whereas none of the population in the control 
counties lived in urban areas (Panel A). By 1850, the level of urbanization in the treatment group had almost tripled to 8.4 percent, an increase of 5.5 percentage points, an increase almost twenty times greater than the increase in the control group's urbanization rate. During the decade of the 1850 s, urbanization in the treatment group increased by another 5.9 percentage points to 14.3 percent of the population in the treatment counties by 1860 whereas the fraction of the population living in urban areas in the control counties in 1860 was still below the level achieved in the treatment group by 1840 .

The differences in population density (Panel B) are not as quite dramatic looking as the differences in urbanization rates between the treatment and control group counties but these differences (which are in logs) are large and the pattern is the same as that in Panel A. Indeed, population density grew especially rapidly in the treatment group of counties in the decade prior to the coming of the railroad. Density in the treatment group of counties more than doubled during the 1840s. In the control counties it still grew rapidly but only by 75 percent. It grew somewhat more slowly in both groups during the 1850 s, especially in the treatment group of counties so that the differences in population density growth between the treatment and control group of counties narrowed sharply during the decade but the treatment counties continued to pull ahead of the control groups.

Indeed, were we to compute the base differences-in-differences estimator using the change in outcomes from 1840 and 1850 reported in Table 3 we would apparently find effects that we attribute to the railroad (the differences between the control and the treatment group) before these could have logically occurred — that is, during the 1840 s, in advance of the railroad coming to any of the counties in the panel (see row 4, column 7, of Panels A and B). 
Table 4: County-Level Correlates of Gaining Rail Access in the 1850s: Linear Probability Regression.

\begin{tabular}{|l|l|l|l|}
\hline & Coefficient & Coefficient & Coefficient \\
\hline Constant & $0.322^{*}$ & $0.332^{*}$ & 0.456 \\
& $(0.098)$ & $(0.124)$ & $(0.150)$ \\
\hline Percent Urban in & 0.093 & 0.246 & 0.614 \\
1840 & $(0.727)$ & $(0.679)$ & $(0.680)$ \\
\hline Log Population & $0.113^{*}$ & 0.013 & -0.001 \\
Density in 1840 & $(0.032)$ & $(0.040)$ & $(0.050)$ \\
\hline$\Delta$ in Percent & 0.635 & $0.916^{*}$ & $0.760^{*}$ \\
Urban, 1850-40 & $(0.380)$ & $(0.361)$ & $(0.371)$ \\
\hline$\Delta$ in Log & $0.187^{*}$ & 0.092 & 0.010 \\
Population & $(0.050)$ & $(0.054)$ & $(0.075)$ \\
Density, 1850-40 & & & \\
\hline Log (Agricultural & & $0.306^{*}$ & $0.308^{*}$ \\
Yield) in 1850 & & $(0.076)$ & $(0.092)$ \\
\hline Canal =1 & & $0.140^{*}$ & 0.125 \\
& & $(0.071)$ & $(0.078)$ \\
\hline Navigable River & & $-0.256^{*}$ & $-0.244^{*}$ \\
$=1$ & & $(0.054)$ & $(0.058)$ \\
\hline Great Lakes $=1$ & & -0.064 & -0.006 \\
& & $(0.120)$ & $(0.124)$ \\
\hline State Dummies & No & No & Yes \\
\hline Adjusted R & 0.067 & 0.177 & 0.200 \\
\hline
\end{tabular}

Source: see text and Table 1. Unit of observation is the county $(\mathrm{N}=278)$. Dependent variable $=1$ if county gains rail access by 1860 (treatment group), 0 otherwise (control group). Agricultural Yield: value of agricultural output/(improved + unimproved acres in agriculture). Observations are weighted by county square miles prior to estimation. Standard errors are shown in parentheses. *: significant at 5 percent level.

The correlations between urbanization and density and treatment that are evident in Panels A and B of Table 3 are symptoms of a more general phenomenon that Fishlow clearly identified -railroads were not built randomly but rather purposely. Railroad promoters and investors did not blindly roll the die on where to locate their line but rather sought out locations where the chances of its success - profitability - were greatest. Table 4 illuminates key correlates of gaining rail access by presenting linear probability regressions. In column 2 , the independent variables are the 1840 values of percent urban 
and $\log$ population density plus the changes in these variables over the 1840s. All of the coefficients are positive and two are statistically significant (the population density variables) at the 5 percent level. In column 3, we have added a measure of agricultural productivity to the regression, the log of the value of agricultural output per acre (that is, the yield), and dummies for water transportation access. Counties that had greater agricultural revenue yields per acre were much more likely to get a railroad. It also appears that canals and railroads were complements, whereas the presence of a navigable river slowed rail expansion, perhaps because this raised the costs of railroad building (i.e. bridges). Column 4 adds state dummies to the regression. Collectively, while these are significant, controlling for individual state effects does not alter the significance of agricultural yields or the navigable river dummy and has only a small impact upon the change in percentage of the population living in urban areas.

Because of the significant explanatory power of these variables for whether or not a county got rail access during the 1850 s and because they may also have a direct effect on the change in urbanization and population density, it is crucial that we control for them if we are to have confidence in our difference-in-difference estimates. Columns 2 and 4 in Table 5 reproduce the base differences-in-differences estimates but computed here within a regression context; by construction these are the same as the effects reported in column 6, row 3 of Panels A and B in Table 3. Columns 3 and 5 present regression estimates of these same coefficients after controlling for the additional variables. This has virtually no effect on our estimate of the coefficient of gaining rail access in the percent urban regression. In the population density regression, however, controlling for the additional variables increases the magnitude and statistical significance of the rail access coefficient. 
Nevertheless, the coefficient on log population density is still absolutely small in magnitude and is not statistically different from the original (unadjusted) estimate.

Table 5: Regression Estimates: Effects of Gaining Rail Access on Urbanization and Population Density: Differences-in-Differences Regressions

\begin{tabular}{|l|l|l|l|l|}
\hline & Percent Urban & Percent Urban & $\begin{array}{l}\text { Log Population } \\
\text { Density }\end{array}$ & $\begin{array}{l}\text { Log } \\
\text { Population } \\
\text { Density }\end{array}$ \\
\hline Rail =1 & $0.037^{*}$ & $0.036^{*}$ & 0.032 & $0.042^{* *}$ \\
$(0.012)$ & $(0.013)$ & $(0.052)$ & $(0.022)$ \\
\hline Year $=1860)$ & & & & \\
multiplied by: & & & & $1.672^{*}$ \\
\hline Percent Urban in & & -0.101 & & $(0.427)$ \\
1840 & $(0.078)$ & & $0.533^{*}$ \\
\hline$\Delta$ (Percent Urban, & & $-0.168^{*}$ & & $0.181)$ \\
$1840-50)$ & $(0.069)$ & & $-0.480^{*}$ \\
\hline Log (Population & & $0.041^{*}$ & & $(0.028)$ \\
Density) in 1840 & & $(0.014)$ & & $-0.375^{*}$ \\
\hline$\Delta$ (Log Population & & $0.065^{*}$ & & $0.040)$ \\
Density, 1840-50) & & $(0.022)$ & & $0.119^{*}$ \\
\hline Log (Agricultural & & 0.030 & & $(0.046)$ \\
Yield) in 1850 & & $(0.023)$ & & 0.016 \\
\hline Canal =1 & & 0.021 & & $0.033)$ \\
\hline Navigable River $=$ & & $(0.013)$ & & 0.031 \\
1 & $0.027^{*}$ & & $(0.026)$ \\
\hline Great Lakes $=1$ & & $(0.013)$ & & 0.125 \\
& & 0.043 & & $0.071)$ \\
\hline State Dummies & & $(0.026)$ & & Included \\
\hline
\end{tabular}

Source: see text and Table 1. Figures outside parentheses are coefficients of Rail $=1$ (county gains rail access in the 1850s). Row1, Base Specification: county and year fixed effects. Row 2: base specification plus interaction terms between (Year $=1860)$ independent variables in Column 4, Table 3. Unit of observation is the county. In the Percent Urban regression, counties are weighted by their average population in 1840 , 1850 , and 1860 . In the density regression, counties are weighted by land area (square miles). Standard errors are clustered by county.

Although adding the additional variables to the differences-in-differences analysis appears to largely validate the conclusions that we reached in our base analyses shown in Panels A and B of Table 3, it is possible that the expanded regressions in Table 5 may 
still suffer from omitted variables bias. That is to say, there may be other factors that are correlated with gaining rail access in the 1850 s that also affected the change in urbanization or the growth rate of population but which are not included in the regression. Therefore, as a robustness check on these estimates we have also estimated the relationship between rail access and urbanization and the log of population density using an instrumental variable. Ideally, from a theoretical standpoint, we would like to go back in time and randomly allocate railroads so as to generate exogenous variation in rail access. While (obviously!) we cannot do this, we can instead approximate the random assignment by finding an instrumental variable for gaining rail access. This is a variable that predicts gaining rail access in the 1850s, controlling for other factors but which is otherwise uncorrelated with the outcomes we are examining.

The historical narrative of internal improvements in America, particularly canal construction, typically assigns an active role to government in promoting these advances. One such source of aid was use of the Army Corp of Engineers to conduct surveys. Beginning in 1824 with the passage of the General Survey Bill, the President was granted authority to survey routes for "such roads and canals as he may deem of national importance, in a commercial or military point of view, or necessary for the transportation of the public mail." (U. S. Congress.) Although the act contains no mention of railroads, beginning in 1825 with a survey to "ascertain the practicability of uniting the headwaters of the Kenawha [sic] with the James river and Roanoke river, by Canals or Railways" (Haney, Lewis H. 1908, p. 277) railroads quickly came to the fore. This law remained in effect until it was repealed by the Jackson administration, effective in 1838. According 
to Haney (1908, p. 283), 61 distinct railroad surveys are mentioned in Congressional documents with 59 being reported.

Our instrument is derived from these government surveys. First, we identified the pair of counties that constitute the starting and endpoint of all railroad surveys listed in American State Papers over the period 1824 to 1838 and reported in Haney (1908, p. 283) — for example, the 1831 railway survey from Portage Summit on the Ohio Canal (near Akron) to the Hudson River (we used Albany as the terminus) (Haney, Lewis H. 1908, p. 286). Many of the authorization were less clear than this one with regard to their endpoints, requiring that some reasonable judgment be made. For example, in 1832, a survey was authorized between the Mad River and Lake Erie in Ohio and, a year later, an appropriation was made for completing reports and drawings for this railroad (Haney, Lewis H. 1908, p. 286). We used Springfield and Sandusky as the termini of this road.

We then draw a straight line between the center of the "start" and "end" counties. Counties that lay along this straight line received a value of one, while those that did not were coded as zero. That is, if a railroad were built, our instrument presumes that it would be built on a straight line, as this is the shortest distance between two points. ${ }^{14}$ Moreover, existence of such a survey raised the likelihood that a railroad would eventually be built because these surveys provided valuable information about topography and other factors that clearly affected potential construction costs. As Taylor (1951, p. 95) notes "[a]s trained engineers were still very scarce ... the government rendered a uniquely valuable service by making its experts available for such surveys." Indeed, Haney (Haney, Lewis H. 1908, p. 284) remarks "It is of some significance that in

\footnotetext{
${ }^{14}$ Our use of a "straight-line" instrument is inspired in part by Bannerjee, Duflo, and Qian (Banerjee, A.; Esther Duflo and Nancy Qian 2006) who construct a similar instrument for their study of the impact of rail access in modern China on wages.
} 
most cases the routes of these government surveys were early taken by railways ... in the great majority of cases these early surveys have been closely followed." Based on when the surveys were taken (mostly in the early 1830s) our "Congressional Survey" instrument is well suited to predict rail access in 1850 - that is, relatively early in the process of railroad building in the Midwest.

Table 6 reports our instrumental variable estimates. Our Congressional Survey instrument does quite well in predicting treatment (gaining rail access in the 1850s) even when we control for all of the other variables included in column 4 of Table 5 (this is the "first stage" coefficient shown in row 2 of Table 6). We use this first stage regression to predict treatment, and then use the predicted value of treatment in the second stage or "two-stage least squares" (2SLS) regression.

Table 6: Instrumental Variables Regressions, 1860 Cross-Section: First Stage and TwoStage Least Squares (2SLS) Coefficients

\begin{tabular}{|l|l|l|}
\hline & Percent Urban & Log Population Density \\
\hline First Stage, Congressional & $0.275^{*}$ & $0.295^{*}$ \\
Survey Instrument & $(0.056)$ & $(0.062)$ \\
\hline 2SLS, Predicted Rail & 0.089 & 0.107 \\
Access & $(0.065)$ & $(0.111)$ \\
\hline Significance Level, 2SLS - & 0.442 & 0.559 \\
DD coefficient of rail & & \\
$\begin{array}{l}\text { access (from Panel A, } \\
\text { column 3 or 5) =0 }\end{array}$ & \\
\hline
\end{tabular}

Sample consists of 1860 cross-section of treatment and control counties. First Stage Coefficient: coefficient of Congressional Survey IV from a regression of rail access in 1860. 2SLS: coefficient of predicted rail access on percent urban or log population density. Other independent variables are the same as in column 4 of Table 3 . Counties in percent urban regression are weighted by the county's average population in 1840, 1850, and 1860; counties in log population density regression are weighted by 1850 land area in square miles. Robust standard errors are shown in parentheses. 2SLS - DD: difference between 2SLS coefficient and differences-in-differences (DID) coefficient from Panel A, column 3 or 5 ( 0.036 , percent urban; 0.042 , log population density). *: significantly different from zero at 5 percent level. 
As can be seen, the 2SLS coefficients, shown in row 3 of Table 6 , are positive and larger than the difference-in-difference coefficients (row 1, columns 3 or 5 of Table 5), indicating the presence of omitted variables in the difference in differences regressions that were negatively correlated with gaining rail access. Fishlow, it should be said, thought as much - he hypothesized that people could anticipate the coming of the railroad. Moreover, hints of this are present in the trends that we see in the 1840s (recall that the treatment counties grow more rapidly than the control counties in the 1840 s, that is, prior to treatment as shown in Table 3). However, while the magnitudes of the 2SLS coefficients are larger than our other estimates of the impact of rail access, they are imprecisely estimated, and we cannot reject the hypothesis that the 2SLS and differenceand-difference coefficients are the same (see row 4, Table 6).

Based upon our analysis and the various other tests we have applied, we have a high degree of confidence in the robustness of our difference-in-difference estimates of the impact that rail access had upon urbanization and population density. Consequently, in Table 7 we have used the differences-in-differences coefficients to compute the "percent explained" - how much of the increase in percent urban or population density can be attributed to the railroad. We do this by multiplying the differences-in-differences coefficients by the change in rail access shown in Table 2, and then dividing by the actual change in the outcome of interest. There are slight differences in this computation between the two columns due to differences in how the data are weighted (urbanization is weighted by population or density is weighted by square miles). 
Table 7: Percent of Urbanization and Population Density Explained by Railroad Expansion, 1850-60

\begin{tabular}{|l|c|l|}
\hline & Percent Urban & Log Population Density \\
\hline Predicted Change, 1850-60 & 0.028 & 0.030 \\
\hline Actual Change, 1850-60 & 0.048 & 0.565 \\
\hline Percent Explained & $58.3 \%$ & $5.3 \%$ \\
\hline
\end{tabular}

Predicted Change: differences-in-differences coefficient from Table 5, column 3 (percent urban) or column 5 (population density) multiplied by change in rail access from 1850 to 1860 ( 0.785 , percent urban calculation; 0.717 , population density calculation). For example, the predicted change in percent urban, $0.028=0.036 \times 0.785$. Percent Explained: Row 2/Row 3 x 100 percent.

Taking the results in Table 7 at face value, the coming of the railroad does not appear to have been a major factor behind Midwestern population growth in the $1850 \mathrm{~s}$, as Fishlow originally thought. However, we do conclude that the railroad was a significant "cause" of Midwestern urbanization, accounting for over half of the increase in the percentage of the population residing in urban places in the sample counties in the $1850 \mathrm{~s}$.

There are three reasons why we might expect to see an effect on urbanization. First, as Fishlow originally pointed out, railroad clearly lowered transportation costs, thereby encouraging trade, especially (as Fogel (1964) showed) relative to intra-regional wagon transportation. This trade has to take place somewhere, and railroads didn't stop in the middle of nowhere. Rather, they stopped in "central places", namely urban areas, especially at points where multiple lines crossed. Second, the gains from trade raised Midwestern incomes and real wages (see Margo 2000) and some of these income gains translated into increased demand for goods and services that were more efficiently produced (and traded) in urban areas. Third, also consistent with Fishlow, once a railroad came to a particular central place in a county, the probability of "feeder lines" connecting 
other towns and villages surely increased; this created an incentive for individuals to move to such places, in advance of the railroad (demand, so to speak, ahead of building).

\section{Conclusion}

This paper has described a new research project, marrying GIS software to digitized archives and enabling the construction of a county-level panel data set which documents the spread of railroads in the Midwestern United States during the middle of the nineteenth century. We have linked these transportation data to standard census data for the period in order to estimate the impact of the coming of the railroad on two important indicator of economic development and settlement- a county's rate of urbanization and the rate of growth of population density.

In his analysis of the dynamics of railroad expansion into the Midwest, Fishlow cautioned that his "newer interpretation may be amended by future research" (Fishlow, Albert 1965, 204). Our analysis does precisely that. Using differences-in-differences supplemented with an instrumental variable approach as a robustness check suggests that the railroad played a quantitatively significant role in the growth of urbanization in the American Midwest around the middle of the nineteenth century but were much less important in the growth of population density. The latter finding is entirely consistent with Fishlow's conclusion. The former issue was not explicitly addressed by Fishlow but represents an important qualification to the generalization of his conclusions. With respect to urbanization, our estimates suggest that the coming of the railroad increased the fraction of population living in urban areas by between 3 and 4 percentage points and 
might account for more than half of the increased urbanization in the Midwest during the $1850 \mathrm{~s}$. 


\section{Bibliography}

Appleton D. and Company. (1848). Appletons' railway and steam navigation guide for the United States and the Canadas. New York, D. Appleton \& Co.

Banerjee, A. E. D. a. N. Q. (2006). "The Railroad to Success: The Effect of Infrastructure on Economic Growth,". Providence, Brown University.

Burr, H. A. (1850). Disturnell's new map of the United States and Canada. New York, Disturnell.

Carter, S. B., S. S. Gartner, et al. (2006). Historical Statistics of the United States Millennial Edition Online. New York, Cambridge University Press.

Cobb, C. (1850). American railway guide and pocket companion for the United States. New York, C. Dinsmore.

Conference on Research in Income and Wealth., National Bureau of Economic Research., et al. (1960). Trends in the American economy in the nineteenth century. A report of the National Bureau of Economic Research, New York. Princeton,, Princeton University Press.

Craig, L. A. Palquist, Raymond B. and Weiss, Thomas (1998). "Transportation improvements and land values in the antebellum United States: a hedonic approach." Journal of real estate finance and economics 16(2): 173-89.

Disturnell, J. (1846). Disturnell's railroad, steamboat, and telegraph book : being a guide through the middle, northern, and eastern states and Canada : also giving the great lines of travel south and west and the ocean steam packet arrangements, containing tables of distances, \&c. telegraph lines and charges, list of hotels, express offices, \&c. \&c. New York, J. Disturnell.

Doggett, J. (1847). Doggett's railroad guide and gazetteer for ... with sectional maps of the great routes of travel. New York, J. Doggett Jr.

Fishlow, A. (1965). American railroads and the transformation of the antebellum economy. Cambridge, Harvard University Press.

Fogel, R. W. (1964). Railroads and American economic growth: essays in econometric history. Baltimore, Johns Hopkins Press.

Goodrich, C. (1961). Canals and American economic development, y Carter Goodrich [and others]. New York, Columbia University Press.

Haney, L. H. (1908). A congressional history of railways in the United States. Madison, Wis., Democrat Printing Co.

Hunt, F., T. P. Kettell, et al. (1848). Hunt's merchants' magazine and commercial review. [New York], Freeman Hunt.

Hunter, L. C. (1949). Steamboats on the Western rivers; an economic and technological history. Cambridge, Harvard University Press.

Inter-university Consortium for Political and Social Research (197?). Historical, Demographic, Economic, And Social Data: The United States, 1790-1970. Ann Arbor, MI., Inter-university Consortium for Political and Social Research

Jenks, L. H. (1944). "Railroads as an Economic Force in American Development." The Journal of Economic History 4(1): 1-20. 
Lloyd, E. (1857). Lloyd's American guide : containing new arranged time tables, so simple and correct that a child can understand them, it being universally acknowledged that all other guide books are so complicated that not one in a hundred can understand them : the population, states, and distances to every place on all the railroad routes in the United States and Canadas : photographic portraits of all the railroad presidents and superintendents--men controlling. Philadelphia, E. Lloyd.

Mitchell, B. R. (2003). International historical statistics. New York, Palgrave Macmillan. National Railway Publication Company. (1868). Travelers' official railway guide of the United States and Canada. Ann Arbor, Mich., printed for the National Railway Publication Co. by University Microfilms.

Oss, S. F. v. (1893). American railroads as investments a handbook for investors in American railroad securities. New York, G.P. Putnam's Sons.

Paskoff, P. F. (2007). Troubled waters : steamboat disasters, river improvements, and American public policy, 1821-1860. Baton Rouge, Louisiana State University Press.

Paxson, F. L. (1914). "The Railroads of the "Old Northwest" before the Civil War." Transactions of the Wisconsin Academy of Sciences, Arts, and Letters 17(Part 1): 247-74.

Poor, H. V. (1860). History of the railroads and canals of the United States. New York, J.H. Schultz \& co.

Poor, H. V. (1868). Poor's manual of railroads. 1st -57th annual number; 1868/69-1924. New York, H.V. \& H.W. Poor.

Rand-McNally (1871). The Rand-McNally official railway guide and handbook. Chicago,.

Taylor, G. R. (1951). The transportation revolution 1815-1860, Holt, Rinehart \& Winston.

Taylor, G. R. and I. D. Neu (1956). The American railroad network, 1861-1890. Cambridge, Harvard University Press.

U. S. Congress. (1823-4). Laws of the U.S. VII, 239. . Acts of 1823-24, Ch. 276.

U. S. Congress., S. (1808). Roads and canals. Communicated to the Senate, April 6, 1808. 